IJTC

Ilomata International Journal of Tax \& Accounting

P-ISSN: 2714-9838; E-ISSN: 2714-9846

Vol. 1 No. 4 October 2020 pp.225-242

https://www.ilomata.org/index.php/ijtc

\title{
The Effect of Organizational Performance, Competitive Advantage on the Financial Sector of Chemical Manufacturing Industry in Banten Province
}

\author{
Uli Wildan Nuryanto ${ }^{1}$, Masyhudzulhak Djamil MZ², Achmad Hidayat Sutawidjaya ${ }^{3}$, Ahmad Badawi Saluy ${ }^{4}$ \\ ${ }^{1234}$ Mercu Buana University \\ Correspondent: uli.wildan11@gmail.com
}

Submitted : September 20,2020 Revised : October 10,2020 Published : October 31, 2020

\begin{abstract}
In current dynamic business environment, the competition is getting stiffer and performance organizational becomes issue, the caracteristics that occurred in the industrial revolution 4.0. This condition requires organizations to increase the performance to be sustain. Competence and knowledge management as internal resources that reffer to RBV are strengths hat are very important as predictors in improving performance. For this reason, the study has explored the indicators of each of the predictors and also test the relationships between latent variable that have been hypothesized. This research focus to the industrial chemical manufactur at Banten Province Indonesia which is become the province with the third largest number of chemical firms in Indonesia. Regarding to the central bureau statistics of Indonesia, the values of productivity and human resources capability from downstream chemical manufactur sector below the target. This research using SEM-PLS method to measure 97 respondents from the level supervisor and manajerial. The final results provide a positive and significant relationship between competence and knowledge management through competitive advantage and organizatioan performance. Competitive advantage also increasse the relationship between competence and knowledge management through the organizational performance. This result has implication for managerial levels to increase human resources performance so it can improve the firm competitive advantage.
\end{abstract}

Keywords: Organizational Performance, Competitive Advantage, Financial Sector Manufacturing Industry

\section{INTRODUCTION}

An increasingly competitive market and consumer awareness of the quality of products purchased at competitive costs, as well as product trends that change according to customer demands have changed the industrial business to be more dynamic (Ko, 2015). This competition started in 1990 when the market was intensified to get the right products and services to their place in a fast and low cost manner ( $\mathrm{Li}$ et al., 2006). This raises impacts and problems, especially for companies that are accustomed to formulating their business strategies by relying on the ability to predict trends in the next five to ten years to change their habits by making changes and rapid innovation (Munir, 2011). To be able to maintain their existence, many companies have made various ways to make changes according to the demands of customers, such as expanding market share (Hertati., 2015), making innovations related to products and services provided to customers (Hertati, 2015), improving production system, make improvements to organizational systems and make cost savings (Hertati, 2016).

Organizations that are not able to keep up with environmental changes will find it very difficult to be able to compete in this competition so that inevitably the organization must be 
The Effect of Organizational Performance, Competitive Advantage on the Financial Sector of Chemical Manufacturing Industry in Banten Province

Nuryanto, Djamil MZ, Sutawidjaya, \& Saluy

able to create a competitive advantage so that its business can survive (Kusuma and Devie, 2013). Hertati research results, (2016) state that competitive advantage is an advantage over competitors that can be obtained by offering greater consumer value, at lower prices or providing greater benefits to customers and providing services that are able to provide more value to customers. customers (Porter, 1985). Competitive advantage is also defined as the ability of an organization to maintain a defensive position against its competitors ( $\mathrm{Li}$ et al, 2006) with indicators of each being price, quality, delivery, dependability, product innovation, and time to market. This is in line with the formulation of competitive advantage proposed by Porter (1985) for companies, namely low cost or product differentiation. In the last 4 years, there has been a very significant decline in growth in the chemical manufacturing sector in Indonesia where the economic growth value of this sector is still below the national economic growth.

This decline occurred in the chemical industry and chemical goods sub-sector, which is the downstream chemical manufacturing industry. The value of productivity and human resource capability in the downstream sector is still below the average value of the non-oil and gas sector where the average value of the productivity and capability of the human resources in the non-oil and gas sector in the last 5 years has been at 398.5 million / person, while the average value of productivity and human resource capabilities The downstream chemical manufacturing industry sector amounted to 336.8 million / person in 2017. This is different from the Upstream chemical manufacturing industry sub-sector which has a productivity value and human resource capacity of 1,211.9 million / person in 2017.

Hertati research (2019) reveals that an increase in existing competitive advantage will be obtained if it is supported by the potential for superior and high-quality human resources to support companies in achieving predetermined quality goals. But unfortunately in fulfilling the needs of human resources itself, there are quite a number of obstacles for the industry today. Based on the results of the Focus Group Discussion (FGD) between key persons of manufacturing industry entrepreneurs, there were problems related to skill gaps, especially in middle-level human resources as well as shortages of supply and skill mismatch at the level of skilled human resources. Hertati, et, all (2020) stated that this is what makes the position of the domestic industry difficult to innovate and develop so that based on the results of the 2017 Global Innovation Index report, the domestic position ranks 87 out of 137 countries in terms of innovation. This illustrates the vulnerability of the industry's ability to be able to develop technology in order to produce high competitiveness. For this reason, a competency-based HR improvement is needed to be able to increase competitive advantage so that it can support an increase in company performance.

Hertati research (2019) states that in addition to free competition, a potential threat but can also be an opportunity in the chemical manufacturing sector is the development of science and technology that has shifted the third industrial revolution into an industrial revolution 4.0 which has a very fast disruptive technology pattern. and threatens incumbent companies. On the other hand, technological developments can actually be used as an opportunity for the industrial manufacturing sector by using automation technology to replace manual systems. Research by Hertati (2016) states that the faster flow of information due to technological advances will help companies to get the flow of information quickly and at low cost. But back to the extent to which the level of human resources in mastering existing competencies and knowledge management to adapt so that they can master renewable technology and even be able to innovate for the company. For this reason, this study seeks to explore existing information related to the influence of competence and how knowledge management plays a role in increasing the competitive advantage of companies in order to improve organizational performance. 
The Effect of Organizational Performance, Competitive Advantage on the Financial Sector of Chemical Manufacturing Industry in Banten Province

Nuryanto, Djamil MZ, Sutawidjaya, \& Saluy

The manufacturing sector is still the largest contributor to the national Gross Domestic Product (GDP) with an achievement of $20.16 \%$ in 2017 . While the next largest contributor to GDP is the agriculture, forestry and fisheries sector at $13.14 \%$, the trade sector at $13.01 \%$, the construction sector was $10.38 \%$ and the mining sector $7.57 \%$. The industrial classification used in the processing industry survey is a classification based on the 4th revision of the Standard Industrial Classification of All Economic Activities (ISIC) which has been adapted to conditions in Indonesia under the name Indonesian Standard Industrial Classification (KBLI) in 2009. Furthermore, the main groups KBLI is divided into 24 industrial subsectors where the chemical industry is included in the 11th classification called the chemical industry and goods made of chemicals. In the last 5 years, the chemical manufacturing industry sector has been able to generate an average export per year of US $\$ 10.83$ billion and has been able to absorb 284,887 productive workforce with 1,376 companies spread across 22 provinces in Indonesia. Of the 22 provinces, there are 3 provinces that have the highest number of chemical companies, including West Java with 388 companies, East Java with 333 companies and Banten province with 292 companies.

Emillia (2015) and Hertati, et, all (2020) state that the manufacturing sector, including the chemical industry, is the foundation for the development of the national economy and is an important sector for sustainable and productive economic growth. The development of the chemical industry in Indonesia is also inseparable from the competitiveness of the industry itself, based on data from The International Institute for Management Development (IMD), the competitiveness of the Indonesian manufacturing industry in the last 11 years is not very good, namely in the 40th rank out of 193 countries registered with the UN. This is an attraction for researchers to conduct more in-depth research related to competitive advantage and organizational performance in the chemical manufacturing industry sector.

The definition of performance is used in various disciplines and depends on the field of the organization itself (Jenatabadi, 2015: Hertati, et, all, 2019). Performance can be defined as an achievement of results that can be seen from the extent to which the organization can achieve goals based on predetermined goals. Performance is the result of collaborative activities among members or organizational components in order to achieve organizational goals. Within the organizational framework, there is a relationship between individual performance and organizational performance. Organizations in achieving predetermined goals must go through activities driven by a person or group of people who actively play a role as actors, in other words the achievement of organizational goals is only possible because of the efforts made by people in the organization. Friedlander and Pickle (1968) and Safkaur, (2020) consider performance as a variable that can measure the success of the company and also measure the extent to which the company's ability to achieve its targets measured through efficiency, effectiveness and others depending on the organizational context. Hertati, et, all (2020) stated that effectiveness refers to the extent to which the production function can meet the demands and requirements of stakeholders such as customers, top management and shareholders. While efficiency is how the organization's resources are economically utilized through the achievement of functions.

This study uses the dimensions of competitive advantage from the perspective of RBV into four dimensions, namely valuable resources, scarce resources, unmatched resources and irreplaceable resources. With the number of indicators as many as seven indicators that refer to the conditions of the research place and also the results of research such as Li and Liu (2018), Ding et al (2018), Gautam and Ghimiee (2016), Stefanikova and Masarova (2014) and Awaad (2014). The indicators are commitment and ability to provide satisfaction to customers (CA1), ability to innovate (CA2), ability to withstand risks (CA3), use of technology (CA4), commitment to achieving goals at any cost (CA5).

Related to RBV, competence is a capital that comes from internal organizations and has value for the organization to be able to produce competitive advantage. In a company, core competence is an absolute force that underlies the company in operating, while in relation to competitive advantage, researchers also use differentiating competencies as a dimension of 
The Effect of Organizational Performance, Competitive Advantage on the Financial Sector of Chemical Manufacturing Industry in Banten Province

Nuryanto, Djamil MZ, Sutawidjaya, \& Saluy

competence. As for professional competence, researchers also use it as a dimension and predictor of competitive advantage and organizational performance, so that it is expected to represent the diversity of meanings related to competence. Otoo and Mishra (2018) and Hertati \& Syafarudin (2018) define competence as a group of knowledge, skills, personal qualities and experiences, while Hellrigel and Slocum (2011) define competence into the dimensions of employee ethical competence, self-competence, diversity competence, cross-cultural competence, communication competence, team competence and changing competencies as the seven main competencies that affect individual competence, team and organizational effectiveness (Hertati, et, all, 2020). Companies make various kinds of efforts to have a competitive advantage as a powerful weapon in improving organizational performance, one of which is by calculating and using core competencies as an internal strength that can produce added value, strong differentiation (Hamel and Prahalad, 1994). There have been many studies from academics which have concluded that core competencies are a very vital force for organizations as a means of gaining competitive advantage (Hafeez and Abdelmeguid, 2003).

Srivastava (2005) states that core competencies are the basis of all internal resources which can be used as competitive advantages. Banerjee (2003), core competence as anything that is information and knowledge about the success or failure of using knowledge sources. Chen and $\mathrm{Wu}$ (2007), core competence as the ability to operate efficiently in a business environment in order to respond to existing challenges. Leonard and Barton (2000), core competencies as competencies that differentiate a company from its environment. Meanwhile, according to Sanchez and Heene (1997) what is meant by core competence is the result of a collective learning process which is manifested in business activities and processes. Professional competence according to McCelland (1973) is defined as the ability needed in the workplace which is related to a person's personal capacity related to one's performance in doing their job. Professional competence refers to the accuracy, skills and exemplary behavior, so that employees must strengthen the professional aspects of competence in order to be competent in carrying out their duties (Mansfield, 1978).

Lysaght and Altschuld (2001) stated that the core of professional competence is knowledge, skills, standards, competences and identification. Distinguishing competencies are abilities, activities and capacities that are unique compared to competitors (Stoner, 1987). Producing higher quality products, innovating, having knowledge and skills in the workplace, or the ability to respond quickly to customer requests compared to customers. Tsou et al (2014); Garcia and Velasco (2008), competencies that differentiate the ability to be able to innovate that produce new methods or materials using technology and leave previous methods. This study uses core competencies as a dimension with three main indicators that refer to the results of research from Hertati, Lestari (2020), Otoo \& Mishra (2018) and Agha et al (2012), the three indicators are competence in communication (COM1), competence in ethics (COM2) and competence to work together (COM3).

Meanwhile, professional competence uses two indicators, namely cognition or understanding of materials (COM4), and the ability to operate existing facilities (COM5) which refers to Ko's research (2015). Whereas for differentiating competence, researchers use one indicator, namely competence to innovate (COM6) which refers to the research of Tsou et al (2014). Knowledge management is the formalization of and access to experience, knowledge, and expertise that creates new capabilities that enable superior performance, drive innovation and increase customer value (Khan, 2012). Knowledge management is a process that helps 
The Effect of Organizational Performance, Competitive Advantage on the Financial Sector of Chemical Manufacturing Industry in Banten Province

Nuryanto, Djamil MZ, Sutawidjaya, \& Saluy

organizations to find, select, organize, disseminate and transfer important information and expertise needed for organizational activities (Zaied et al, 2012). Companies that are efficient in acquiring knowledge will be able to create and maintain a competitive advantage in a knowledgebased economy. Meanwhile, other companies that are unable to acquire and create knowledge will have difficulty in maintaining their competitive position (Deed and Hill, 1996 in Khan 2012). Knowledge is an important source of competitive advantage available to an organization in the twenty-first century (McFadyen and Canella, 2004).

The twenty-first century is an era of knowledge economy, where most organizations have knowledge that enables them to improve their organizational performance (Zaied et al, 2012). In today's world of aggressive competition, knowledge management is the main vehicle for organizations to achieve their goals and to compete well. Knowledge management is recognized as an important weapon to maintain competitive advantage and improve performance (Zaied et al, 2012). Through knowledge management, organizations identify their knowledge and use it to improve performance and produce various innovations (Munir, 2011). Organizations must recognize the importance of effective knowledge management, because the costs of ignoring it are enormous (Ling et al, 2008). So that the evaluation of knowledge management becomes important because it provides a reference to direct the organization in increasing competitive advantage so that it can create good organizational performance.

The dimensions of knowledge management in this study are identified into five stages of knowledge selection that have been adjusted to the place of research and refer to the research of Mahdi et al (2018), Turulja and Bajgoric (2018), Cahyaningsih et al (2017), Mahdavi and Pirzad (2017). Al-Refaie and Al-Tahar (2016), Hazen (2015) into the process of knowledge identification, knowledge creation, knowledge storage, knowledge sharing and knowledge use. With the number of research indicators as many as six indicators, namely data collection on potential knowledge (KM1), converting and formalizing knowledge into reference standards (KM2), protection of knowledge (KM3), transfer of knowledge (KM4), sharing of knowledge (KM5) and use of knowledge into activities operational routine (KM6). This study integrates the resources based view (RBV) theory and knowledge based theory (KBV), so that the researcher calls the concept of renewal in this study as the Gain Competitive Advantage for a reliable industry, this study also develops several hypotheses to extend the existing model into a new model. From the description above it can be formulated a research hypothesis that competitive advantage, organizational performance affects the manufacturing industry sector

\section{METHODS}

This research is designed to answer problems that have been formulated through hypotheses. Kerlinger's (2000) design is an investigation structure structured in such a way as to help researchers get definite answers. using a deductive approach consisting of exploratory research to find some relatively new relationships and detailed explanations. By applying a deductive approach, the researcher tries to see the data empirically and systematically which is then compared with existing theories. Causal studies attempt to explain the relationship between the influence of competence, knowledge management, and competitive advantage on organizational performance in the chemical manufacturing sector. The conceptual framework proposed by the researcher is as follows: 
The Effect of Organizational Performance, Competitive Advantage on the Financial Sector of Chemical Manufacturing Industry in Banten Province

Nuryanto, Djamil MZ, Sutawidjaya, \& Saluy

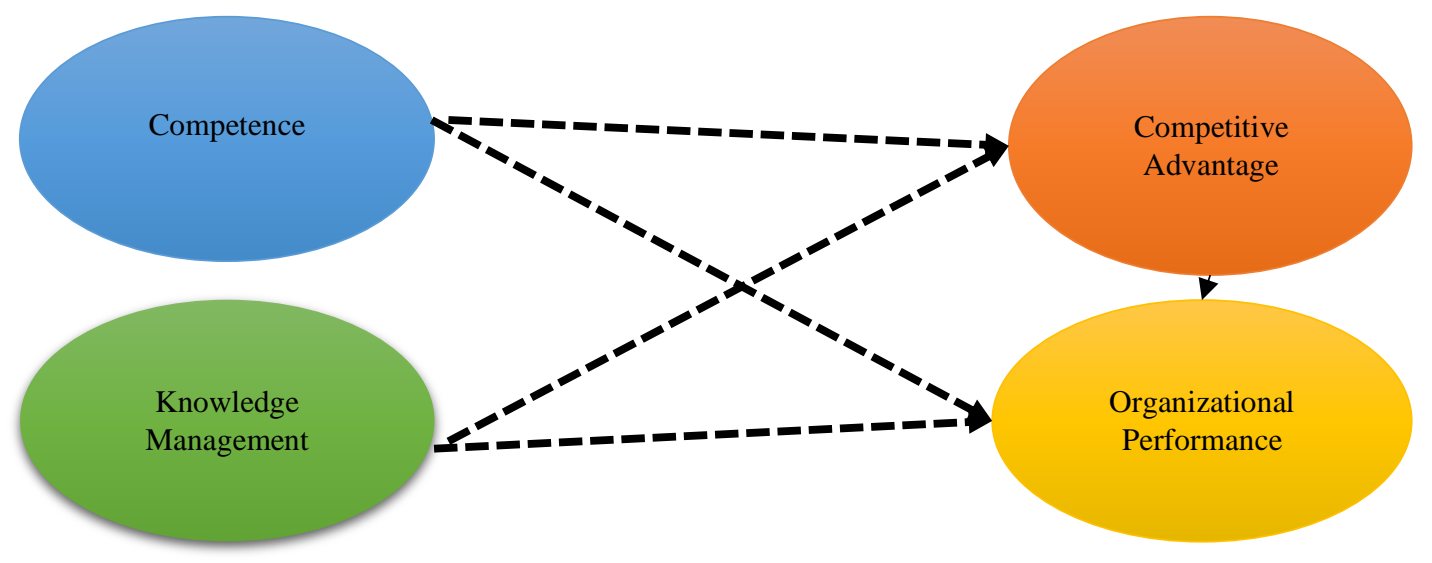

Figure 1. Research Framework, 2020

This research was conducted on chemical companies in the province of Banten which are scattered in Serang Regency, Cilegon City and Tangerang Regency involving 97 respondents. The sampling technique uses purposive sampling technique and the unit of analysis measures the managerial level employees as policy makers in their respective companies with a minimum working period of one year. The variables in this study are grouped into three groups, the first exogenous variables are competence and knowledge management. , the second is the intervening variable, namely competitive advantage and the last is the endogenous variable, namely organizational performance. This study uses a questionnaire with a Likert scale with a value of 1 5 where scale 1 states strongly disagree, scale 2 disagrees, scale 3 is neutral, scale 4 agrees and scale 5 strongly agrees.

\section{RESULTS AND DISCUSSION}

This study aims to obtain the best model in explaining the influence of competence, knowledge management and competitive advantage on organizational performance in the chemical manufacturing sector. While the indicators used are those that refer to previous research and are related to the place of this research. The data analysis technique uses SEM PLS, according to Ferdinand (2002) SEM is very suitable for confirming various kinds of constructs that exist for latent variables. Test model compatibility or accuracy based on observed empirical data. Test the causal relationship between the factors observed in the model. Based on the results of an in-depth literature review of each relationship between variables, the following relationships and influences were obtained.

The results of previous research show that competence and quality have a significant effect on competitive advantage in small and medium companies (Ismail et al, 2014). Meanwhile, the research results of Adiputra and Mandala (2017) show that competence and capability have a positive effect on company performance, but competence does not have a significant effect, while capability has a significant effect. Agha et al (2012), Jamhour and Agha (2010) and Hastjarjo, et al (2016) show that competence has a significant effect on competitive ability and competitive advantage and can improve organizational performance. Based on the research that has been done above in relation to the relationship between competence and competitive advantage, the researchers took the following provisional conclusions: 
The Effect of Organizational Performance, Competitive Advantage on the Financial Sector of Chemical Manufacturing Industry in Banten Province

Nuryanto, Djamil MZ, Sutawidjaya, \& Saluy

HI: Competence has a significant effect on competitive advantage in the industrial sector chemical manufacturing

The results of research related to the relationship between knowledge management and competitive advantage found that there is a significant relationship between knowledge management and competitive advantage (Mahdi et al, 2018). Meanwhile, Kusuma and Devie's (2013) research results show that knowledge management has a positive and significant impact on competitive advantage and organizational performance. Nazarpour and Shirin (2017) The human resource process has a positive and significant influence on knowledge management and competitive advantage, as well as knowledge management which has a significant effect on competitive advantage where the measurement of competitive advantage is through the VRIO approach. Almasi and Pirzad (2017) conclude that intellectual capital has a significant effect on knowledge management and competitive advantage, but knowledge management has no significant effect on competitive advantage, while Lee et al (2016) conclude that knowledge management has a significant effect on technological innovation and competitive advantage. and technological innovation has a significant effect on competitive advantage. Based on the research that has been done above in relation to the relationship between knowledge management and competitive advantage, the researchers took the following provisional conclusions:

H2: Knowledge Management has a significant effect on competitive advantage in chemical manufacturing industry sector.

Previous research that discussed the relationship between competitive advantage and organizational performance such as Cantele and Zardini (2018) concluded that there was a significant influence on the sustainability dimension of the long-term company on competitive advantage and a significant effect on competitive advantage and company performance. Lorenzo et al (2017) concluded that competitive advantage has a significant effect on the performance of beverage companies in Spain, this is in line with the research of Othman et al (2015), Kusuman and Devie (2013) and Gyampah and Acquaah (2008) where their research also emphasizes that the source the company's existing power originating from the internal company will determine the company's competitive advantage. Based on the research that has been done above in relation to the relationship between knowledge management and competitive advantage, the researchers took the following provisional conclusions:

H3: Competitive advantage has a significant effect on organizational performance in the sector chemical manufacturing industry

Previous studies that examined the relationship between competence and organizational performance include Otoo and Mishra (2018) which concluded that good human resources will increase employee competence and the impact will have a significant effect on organizational performance, while Nimsith et al (2016), Agha et al. (2012), Jamhour and Agha (2010) and Hastjarjo et al (2016) concluded that the dynamic ability of organizations to existing environmental risks and competence has a significant effect on organizational performance. So that it can be concluded that competence is a very valuable internal resource for the company to be able to improve its organizational performance. Based on the research that has been done above in relation to the relationship between competence and organizational performance, the researchers took the following temporary conclusions:

H4: Competence has a significant effect on organizational performance in the sector chemical manufacturing industry 
The Effect of Organizational Performance, Competitive Advantage on the Financial Sector of Chemical Manufacturing Industry in Banten Province

Nuryanto, Djamil MZ, Sutawidjaya, \& Saluy

The influence between knowledge management on organizational performance, it is concluded that there is a positive and significant relationship, this is in line with the results of Almudallal's research (2015), but in his research he has a very high amount of influence, which is $70 \%$. Knowledge management supported by information technology applications will also have a significant effect on company performance (Lopez and Alegree, 2011). Meanwhile, Nowacki and Bachnick (2015) concluded that there is a significant influence between knowledge management on company effectiveness in terms of innovation ability, company revenue, competitiveness. Meanwhile, Muthuveloo et al (2017) stated that there was a significant influence on the dimensions of knowledge management, namely socialization and internalization on company performance. Based on the research that has been done above in relation to the relationship between knowledge management and organizational performance, the researchers draw the following temporary conclusions:

H5: Knowledge management has a significant effect on organizational performance on chemical manufacturing industry sector.

Based on the results of the descriptive test of respondents, the majority of the results were as follows: The majority of respondents were male (69.1\%), the majority of respondents were 30 40 years old $(46.4 \%)$, the majority of the working years were $11-15$ years $(36.1 \%)$. The majority of education is undergraduate $(76.3 \%)$, the majority position is Supervisor $(29.9 \%)$.

Tabel 1.

Demographic Respondents

\begin{tabular}{|c|c|c|}
\hline Profile & Frequency & $\%$ \\
\hline \multicolumn{3}{|l|}{ 1. Gender } \\
\hline Male & 67 & 69,1 \\
\hline Female & 30 & 30,9 \\
\hline \multicolumn{3}{|l|}{ 2. Age } \\
\hline$<30$ Years & 11 & 11,3 \\
\hline $30-40$ years & 45 & 46,4 \\
\hline 41-50 Years & 32 & 33 \\
\hline$>50$ Years & 9 & 9,3 \\
\hline \multicolumn{3}{|l|}{ 3. Service Years } \\
\hline 0-5 Years & 11 & 11,3 \\
\hline 6-10 Years & 18 & 18,6 \\
\hline 11-15 Years & 35 & 36,1 \\
\hline 16-20 Years & 22 & 22,7 \\
\hline 21-25Years & 8 & 8,2 \\
\hline$>25$ Years & 3 & 3,1 \\
\hline \multicolumn{3}{|l|}{ 4. Education } \\
\hline Diploma & 13 & 13,4 \\
\hline Bachelor Degree & 74 & 76,3 \\
\hline Master Degree & 10 & 10,3 \\
\hline \multicolumn{3}{|l|}{ 5. Position } \\
\hline Supervisor & 29 & 29,9 \\
\hline Sect. Head & 18 & 18,6 \\
\hline Ass. Manager & 24 & 24,7 \\
\hline Manager & 22 & 22,7 \\
\hline GM & 4 & 4,1 \\
\hline
\end{tabular}

Source: Data Processing Results, 2020 
The Effect of Organizational Performance, Competitive Advantage on the Financial Sector of Chemical Manufacturing Industry in Banten Province

Nuryanto, Djamil MZ, Sutawidjaya, \& Saluy

Outer Model Analysis Result. The results of the convergent validity indicators of each variable are as follows; competency variables with indicators COM1, COM2, COM3, COM4, COM5 and COM 6 respectively $0.734,0.823,0.657,0.717,0.688$ and 0.793 . Knowledge management variable with indicators KM1, KM2, KM3, KM4, KM5 and KM6 respectively $0.777,0.795,0.799,0.820,0.817$ and 0.801 . The variable of competitive advantage with indicators CA1, CA2, CA3, CA4 and CA5 respectively 0.809, 0.697, 0.911, 0.774 and 0.842 . Organizational performance variables with indicators OP1, OP2, OP3, OP4 and OP5 respectively $0.745,0.822$, $0.756,0.812$, and 0.869 . The result of the loading indicator test is recommended to be above 0.70 , but as long as the model is still in the development stage, the loading indicator value of 0.60 is still tolerable. From the test results above, it shows that each indicator of each competency variable, knowledge management, competitive advantage and organizational performance shows a result above 0.60 . Composite Reliability

Table 2.

Value of Composite Reliability

\begin{tabular}{lc}
\hline \multicolumn{1}{c}{ Construct } & Composite Reliability \\
\hline Competence & 0,877 \\
\hline Competitive Advantage & 0,904 \\
\hline Knowledge Management & 0,915 \\
\hline Organizational Performance & 0,900 \\
\hline
\end{tabular}

Source: Data Processing Results, 2020

The expected composite reliability value from the test results is ditas 0.70 which illustrates that each indicator has high consistency for measuring latent variables. The results showed that each construct had a composite reliability value above 0.70 , which indicates the consistency of the construct to measure high latent variables. Average Variance Extracted (AVE)

Table 3.

Average Variance Extract

\begin{tabular}{ll}
\hline \multicolumn{1}{c}{ Construct } & AVE \\
\hline Competence & 0,544 \\
\hline Competitive Advantage & 0,656 \\
\hline Knowledge Management & 0,642 \\
\hline Organizational Performance & 0,643 \\
\hline Source: Data Processing Results, 2020 &
\end{tabular}

The AVE value shows the variance value for each indicator in the construct that is captured by these variables more than the variance caused by measurement errors. The recommended AVE value is $>0.5$. From the analysis, it was found that the AVE value for each construct was greater than 0.50.Cronbach's Alpha.

Table 4.

Cronbach's Alpha

\begin{tabular}{lc}
\hline \multicolumn{1}{c}{ Construct } & Cronbach's Alpha \\
\hline Competence & 0,9738 \\
\hline Competitive Advantage & 0,9419 \\
\hline Knowledge Management & 0,9863 \\
\hline Organizational Performance & 0,9482 \\
\hline Source: Data Processing Results, 2020.
\end{tabular}

Goodness of fit test. The goodness of fit test results obtained R2 value for the construct of competitive advantage of 0.651 which can be interpreted that competence and knowledge 
The Effect of Organizational Performance, Competitive Advantage on the Financial Sector of Chemical Manufacturing Industry in Banten Province

Nuryanto, Djamil MZ, Sutawidjaya, \& Saluy

management have an impact on competitive advantage by $65.1 \%$ while the remaining $34.9 \%$ is influenced by other variables. Whereas for the value of $\mathrm{R} 2$ construct organizational performance has R2 of 0.678 which means, organizational performance is influenced by latent variables of competitive advantage, competence and knowledge management by $67.8 \%$, while the remaining $32.2 \%$ is influenced by other variables.

Table 5.

Value of R-Square

\begin{tabular}{lc}
\multicolumn{1}{c}{ Construct } & R-Square \\
\hline Organizational Performance & 0,678 \\
\hline Competitive Advantage & 0,651 \\
\hline
\end{tabular}

Source: Data Processing Results, 2019

Hypothesis Test. To answer the hypothesis that has been, it is seen the significance of the influence between independent constructs on the dependent at the 5\% significance level. The results of the T-Statistics value are as follows:

Tabel 6.

Coefficients value (Original Sample), Standard Error and T-Statistics

\begin{tabular}{lccccc}
\hline \multicolumn{1}{c}{ Significance Test } & $\begin{array}{c}\text { Original } \\
\text { Sample } \\
(\mathrm{O})\end{array}$ & $\begin{array}{c}\text { Standard } \\
\text { Error } \\
\text { (STERR })\end{array}$ & $\begin{array}{c}\text { T Statistics } \\
(\mid \text { O /STERR } \mid)\end{array}$ & P Values & Result \\
\hline $\begin{array}{l}\text { Competence -- }>\text { Competitive } \\
\text { Advantage }\end{array}$ & 0,206 & 0,094 & 2,196 & 0,029 & Significant \\
\hline $\begin{array}{l}\text { Competence -- }>\text { Organizational } \\
\text { Performance }\end{array}$ & 0,212 & 0,126 & 1,979 & 0,046 & Significant \\
\hline $\begin{array}{l}\text { Competitive Advantage -- }> \\
\text { Organizational Performance }\end{array}$ & 0,532 & 0,018 & 4,494 & 0,000 & Significant \\
\hline $\begin{array}{l}\text { Knowledge Management -- } \\
\text { Competitive Advantage }\end{array}$ & 0,653 & 0,080 & 8,173 & 0,000 & Significant \\
\hline $\begin{array}{l}\text { Knowledge Management -- }> \\
\text { Organizational Performance }\end{array}$ & 0,571 & 0,112 & 5,103 & 0,000 & Significant \\
\hline
\end{tabular}

Source: Data Processing Results, 2019

Hypothesis 1. Bootstrapping test results obtained the coefficient value of the latent variable competence on competitive advantage of 0.206 indicating that competence has a positive influence on competitive advantage. As for the T-Statistic value, the value is 2.196 where this value is greater than 1.96 and the $\mathrm{P}$ value of 0.0296 is smaller than 0.05 , which indicates that competence has a significant effect on competitive advantage, so that H1 in this study can be accepted. This significance is in line with the results of research by Ismail et al. (2014) which showed a significant relationship between competence and competitive advantage in small and medium enterprises (SMEs), as well as the results of research by Hastjarjo et al (2016) which showed the same results in the real industry. estate. Meanwhile, Agha et al (2012) and Jamhour and Agha (2010) show the same results in the painting industry.

Hypothesis 2.The Bootstrapping test results show that the coefficient of knowledge management latent variable on competitive advantage is 0.653 indicating that competence has a positive influence on competitive advantage. As for the T-statistic value, the value of 8.173 is obtained where this value is greater than 1.96 and the $\mathrm{P}$ value of 0.000 is less than 0.05 , which indicates that knowledge management has a significant effect on competitive advantage, so that $\mathrm{H} 2$ in this study can be accepted. This significance is in line with the results of research conducted by Mahdi et al (2018) whose research was conducted at universities in relation to 
The Effect of Organizational Performance, Competitive Advantage on the Financial Sector of Chemical Manufacturing Industry in Banten Province

Nuryanto, Djamil MZ, Sutawidjaya, \& Saluy

industry as users. Meanwhile, Kusuma and Devie (2013) show the same relationship results where their research was conducted on 100 managerial private companies in Surabaya. Meanwhile, the research results of Nazarpour and Shirin (2017) show the same results, but in the port industry in Iran. Almasi and Pirzad (2017), show the results of the same relationship between knowledge management and competitive advantage in the banking industry and Lee et al (2016) in small and medium enterprises (SMEs) in Malaysia.

Hypothesis 3. Bootstrapping test results show that the coefficient of the latent variable of competitive advantage on organizational performance is 0.532 , indicating that competitive advantage has a positive influence on organizational performance. Whereas for the T-statistic value, the value is 4.494 where this value is greater than 1.96 and the $\mathrm{P}$ value is 0.000 less than 0.05 , which indicates that competitive advantage has a significant effect on organizational performance, so that $\mathrm{H} 3$ in this study can be accepted. This significance is in line with the results of research conducted by Cantele and Zardini (2018) which show significant results for small and medium industries in Italy, while Lorenzo et al (2017) in the Spanish wine industry, Othman et al (2015) on cooperatives registered in Malaysia, Kusuma and Devie (2013) for private companies in Surabaya, and Gyampah and Acquaah (2008) for companies in Ghana.

Hypothesis 4. Bootstrapping test results obtained the coefficient value of the latent variable competence on organizational performance of 0.212 , indicating that competence has a positive influence on organizational performance. As for the T-statistic value, the value is 1.979 where this value is greater than 1.96 and the $P$ value of 0.046 is smaller than 0.05 , which indicates that competence has a significant effect on organizational performance, so that $\mathrm{H} 4$ in this study can be accepted. This significance is in line with the results of research conducted by Otoo and Mishra (2018) which show significant results for the hotel industry in India, while Hastjarjo et al (2016) on the real estate industry in Indonesia, Nimsith et al (2016) on the banking industry in Sri Lanka., Agha et al (2012) and Jamhour and Agha (2010) on the painting industry in the UAE. These results indicate that competence is a predictor of organizational performance that can increase employee commitment to the company, economic performance, social performance and environmental performance.

Hypothesis 5. The results of Bootstrapping test showed that the coefficient value of the latent variable competence on organizational performance was 0.571 which shows that competence has a positive influence on organizational performance. Whereas for the T-statistic value, the value of 5.103 is obtained where this value is greater than 1.96 and the $\mathrm{P}$ value of 0.000 is less than 0.05 , which indicates that knowledge management has a significant influence on organizational performance, so that $\mathrm{H} 5$ in this study can be accepted. This significance is in line with the results of research conducted by Meiranto et al (2012) showing significant results for the banking industry in Indonesia, while Almudallal et al (2015) in the public sector in Palestine, Nowacki and Bachnik (2015) on private companies in Poland and Muthuveloo et al (2017) in local and foreign manufacturing industries registered with the Federation of Malaysian Manufacturers. These results indicate that knowledge management is a predictor of organizational performance. Competitive advantage as a mediator variable

a. The indirect coefficient of competence on organizational performance through competitive advantage is $0.206 \times 0.532=0.1096$. Calculation of the $Z$ value using the Sobel test is obtained as follows:

$$
z=\frac{a b}{\sqrt{\left(b^{2} S E_{a}^{2}\right)+\left(a^{2} S E_{b}^{2}\right)}}
$$


The Effect of Organizational Performance, Competitive Advantage on the Financial Sector of Chemical Manufacturing Industry in Banten Province

Nuryanto, Djamil MZ, Sutawidjaya, \& Saluy

$$
\begin{aligned}
& z=\frac{0.206 \times 0.532}{\sqrt{\left(0.206^{2} \times 0.094^{2}\right)+\left(0.532^{2} \times 0.018^{2}\right)}} \\
& z=\frac{0.1096}{\sqrt{0.00045}} \\
& z=5.48
\end{aligned}
$$

Where

$\mathrm{a}=$ Coefficient of influence of competence on competitive advantage

$\mathrm{b}=$ coefficient of influence of competitive advantage on organizational performance $\mathrm{SEa}=$ standard error of competence on competitive advantage

$\mathrm{SEb}=$ standard error of competitive advantage on organizational performance

With a Z score of 5.48 greater than Z 1.98, it can be concluded that competitive advantage is able to mediate the relationship between competence and organizational performance.

a. The indirect coefficient of knowledge management on organizational performance through competitive advantage is $0.206 \times 0.532=0.1096$. Calculation of the $\mathrm{Z}$ value using the Sobel test is obtained as follows:

$$
\begin{aligned}
& z=\frac{a b}{\sqrt{\left(b^{2} S E_{a}^{2}\right)+\left(a^{2} S E_{b}^{2}\right)}} \\
& z=\frac{0.653 \times 0.532}{\sqrt{\left(0.532^{2} \times 0.080^{2}\right)+\left(0.653^{2} \times 0.018^{2}\right)}} \\
& z=\frac{0.3474}{\sqrt{0.0019}} \\
& z=7.89
\end{aligned}
$$

Where :

$\mathrm{a}=$ Coefficient of influence of competence on competitive advantage

$\mathrm{b}=$ coefficient of influence of competitive advantage on organizational performance

$\mathrm{SEa}=$ standard error of competence on competitive advantage

$\mathrm{SEb}=$ standard error of competitive advantage on organizational performance

With a $Z$ score of 7.89 greater than Z 1.98, it can be concluded that competitive advantage is able to mediate the relationship between knowledge management and organizational performance.

\section{CONCLUSION}

The role of competitive advantage on organizational performance is very important, this can be proven where competitive advantage is able to increase the influence of competence and knowledge management on organizational performance. Competence has a positive and significant effect both on competitive advantage and on organizational performance, as well as knowledge management which has a positive and significant effect on competitive advantage and organizational performance. This study has implications for managers and control holders in the company to be able to improve the competence of existing human resources by using the existing dimensions of professional competence, core competence and unique differentiating competences. By improving these three competencies, it will be able to improve company performance in terms of commitment, economic performance, social performance and environmental performance. Another implication is related to knowledge management which can be used as a predictor for company managers which in this study is described into the dimensions of knowledge identification, knowledge creation, knowledge storage, knowledge sharing and knowledge use. The existence of good management of knowledge is an important asset for companies in facing the industrial revolution 4.0 which leads to a knowledge-based 
The Effect of Organizational Performance, Competitive Advantage on the Financial Sector of Chemical Manufacturing Industry in Banten Province

Nuryanto, Djamil MZ, Sutawidjaya, \& Saluy

economy. This research is not without drawbacks, given the limited number of respondents and the variables used. It is hoped that further research can be continued by using more comprehensive variables based on the RBV theory and also with a larger number of samples from this study.

\section{REFERENCES}

Adiputra, I.P.P., \& Mandala, K., (2017). Pengaruh Kompetensi dan Kapabilitas Terhadap Keunggulan Kompetitif dan Kinerja Perusahaan. E-Jurnal Manajemen Unud. 6(11): 60906119.

Agha, S., Alrubaiee, L., \& Jamhour, M., (2012). Effect of Core Competence on Competitive Advantage and Organizational Performance. International Journal of Business and Management. 7(1): 192-204.

Almasi, F., \& Pirzad, A., (2017). The Effect of Intellectual Capital and Knowledge Management on Competitive Advantage: Testing the Mediating Role of Customer Relationship Management. International Journal of Economic Perspective. 11(3): 895-904.

Almudallal, A.W., Bakri, N., Muktar, S.N., \& El-farra, M.M., (2015). Implementing Knowledge Management in the Palestinian Public Sector Institutions: Empirical Study on the Presidency of the Palestinian Government. International Review of Management and Marketing. 6(S4): 101-107.

Al-Refaie, A., \& Al-Tahar, M., (2015). Effect of Knowledge Management and Organizational Learning on Firm Performance. Journal of Nature Science and Sustainable technology. 8(3): 369-390.

Ansoff, I. (1965). Corporate Strategy. New York: McGraw-Hill, 1965.

Awaad, A.S., Al khattab, A.A., \& Anchor, J.H., (2013). Competitive Priorities and Competitive Advantage in Jordanian Manufacturing. Journal of Service Science and Management. 6: 6979 .

Banerjee, P., (2003). Resource Dependence and Core Competence: Insights from Indian Software Firms, Technovation, 23: 251-263.

Barney, J., (1991). Firm Resources and Sustained Competitive Advantage. Journal of Management. 17(1): 99-120.

Cahyaningsih, E., Sensuse, D.A., Arymurthy, A.M., \& Wibowo, W.C., (2017). NUSANTARA: A New Model of Knowledge Management in Government Human Capital Management. Procedia Computer Science. 124: 61-68.

Cantele, S., \& Zardini, A., (2018). Is sustainability a competitive advantage for small businesses? An empirical analysis of possible mediators in the sustainabilityefinancial performance relationship. Journal of Cleaner Production. 182: 166-176.

Chen, Y. F., \& Wu, T. C., (2007). An empirical analysis of core competence for high-tech firms and traditional manufacturers. Journal of Management Development, 26, 2, 159-168.

Deeds, D.L., \& Hill, C.W.L., (1996). Strategic Alliances and the Rate of New product Development: An Empirical Study of Entrepreneurial biotechnology Firms. Journal of Business Venturing. 11: 41-55.

Ding, H., Fu, Y., Zheng, L., \& Yan, Zh., (2018). Determinants of the competitive advantage of dairy supply chains: Evidence from the Chinese dairy industry. International Journal of Production Economics. 1-42. 
The Effect of Organizational Performance, Competitive Advantage on the Financial Sector of Chemical

Manufacturing Industry in Banten Province

Nuryanto, Djamil MZ, Sutawidjaya, \& Saluy

Emilia, H., (2015). The importance of the manufacturing sector in the Romanian economy. Procedia Technology. 22: 976-983.

Ferdinand, A. (2002). Structral Equation Modelling dalam penelitian manajemen. Semarang: FE UNDIP.

Friedlander, F., \& Pickle, H., (1968). Components of Effectiveness in Small Organizations. JSTOR. 13(2): 289-304.

Garcia, C.Q., \& Velasco, C.A.B., (2008). Innovative competence, exploration and exploitation: The influence of technological diversification. Research Policy. 37: 492-507.

Gautam, D.K., \& Ghimire, S.B., (2016). Psychological empowerment of employees for competitive advantages An empirical study of Nepalese service sector. International Journal of Law and Management. 59(4): 466-488.

Gyampah, K.A., \& Acquaah, M., (2008). Manufacturing strategy, competitive strategy and firm performance: An empirical study in a developing economy environment. International Journal of Production Economics. 111: 575-592.

Hafeez, K., \& Abdelmeguid, H., (2003). Dynamics of human resource and knowledge management. Journal of the Operational Research Society, 54(12), 153-164.

Hameed, Imran. (2009). Sources of Business Competitive Advantage: A Review. Journal of Business \& Economics. 222-233.

Hamel, G. \& Prahalad, C.K. (1994). Competing for The Future. Boston : Harvard Business School Press.

Hastjarjo, K., Yahya, D.K., Afiff, F., \& Rufaidah, P., (2016). Core Competence on Real Estate Industry in Globalization Phenomenon: A Contemporary Approach. International Journal of Economics and Financial Issues. 6(5): 14-19.

Hazen, B.T., (2015). Knowledge Management for Logistic Service Providers: The Rule of Learning Culture. Industrial Management and Data System. 116(3): 584-602

Hellriegel, D \& Slocum, J. W. (2011). Organizational Behavior. Mason: SouthWestern, Cengage Learning.

Hertati, L (2015). Competence of Human Resources, The Benefits of Information Technology on Value of Financial Reporting in Indonesia. Research Journal of Finance and Accounting 6, (8) 12-18

Hertati, L.(2015). Impact of uncertainty of environment and organizational cultural on accounting information system management and implications for managerial performance proposing a conceptual framework. International Journal of Economics, Commerce and Management United Kingdom 3 (12) 455-468.

Hertati, L. (2015). Total Quality Management As Technics On Strategic Management Accounting. International Journal of Recent Advances in Multidisciplinary Research 2, (11),.0942-0949

Hertati, L.\& Zarkasyi, W. (2015). Effect Of Competence User Information System, The Quality Of Accounting Information Systems Management And Implications Insatisfaction User Information System (State Owner In Sumatera Selatan. European Journal of Accounting, Auditing and Finance Research 3, (2).35-60.

Hertati, L. (2015). Internal Control And Ethics Of Quality Management System Accounting Information And Implications On The Quality Of Accounting Information Management: Proposing A Research Framework. International Journal of Economics, Commerce and Management United Kingdom 3 (6) 902-913 
The Effect of Organizational Performance, Competitive Advantage on the Financial Sector of Chemical

Manufacturing Industry in Banten Province

Nuryanto, Djamil MZ, Sutawidjaya, \& Saluy

Hertati, L. \& Sumantri R. (2016). Just In Time, Value Chain, Total Quality Management, Part Of Technical Strategic Management Accounting. International Journal Of Scientific \& Technology Research 5( 4) 181-191

Hertati, L \& Syafarudin.A. (2018). How the Implementation of the Industrial Revolution 4.0 Management Information System Influenced Innovation: The Case of Small and Medium Enterprises in Indonesia. Journal of Asian Business Strategy. 8 ( 2) 52-62

Hertati, L., Zarkasyi.W., Suharman. H., \& Umar. H. (2019). The Effect of Human Resource Ethics on Financial Reporting Implications for Good Government Governance (Survey of Related Sub-units in State-owned Enterprises in SUMSEL). International Journal of Economics and Financial. 9(4), 267-276

Hertati, L, Susanto. A. Zarkasyi. W, Suharman. H, \& Umar. H. (2019). Pengujian Empiris Bagaimana Kualitas Sistem Informasi Akuntansi Yang Dipengaruhi Oleh Etika Organisasi Berimplikasi Terhadap Kualitas Informasi Akuntansi (Surveypada Badan Usaha Milik Negara (Bumn) Di Sumatera Selatan Indonesia). Jurnal Ilmiah Akuntansi Rahmaniyah (JIAR) 3 (1) $88-107$.

Hertati, L \& Safkaur. (2020). The Influence of Information Technology Covid-19 Plague Against Financial Statements and Business Practices IJTC Ilomata International Journal of Tax \& Accounting. 1 (3) 122-131

Hertati, L, Safkaur. O, \& Simanjuntak.O.M.(2019). How to Align Management Commitments to the Successful Implementation of Management Accounting Information Systems in Manager Decision Making. IJTC Ilomata International Journal of Tax \& Accounting 1 (2) 89.93.

Hertati, L, \& Safkaur.O, (2019). Impact Of Business Strategy On The Management Accounting: The Case Of The Production Of State-Owned Enterprises In Indonesia, South Sumatra. Journal of Asian Business Strategy 9, ( 1) 29-39.

Hertati, L. Widiyanti. M. Desfitrina. \& Syafarudin. A. (2020). The Effects Of Economic Crisis On Business Finance. International Journal of Economics and Financial Issues 10, (3) 236244.

Hertati, L, Fery.I, \& Safkaur. O. (2020). Pengaruh Komitmen Organisasi Terhadap Sistem Informasi Keuangan. Akuntabilitas: Jurnal Ilmu Akuntansi Volume 13 (1),125-136.

Ismail, M.D., Domil, A.K.A., \& Isa, A.M., (2014). Managerial Competence, Relationship Quality and Competitive Advantage among SME Exporters.Procedia Social and Behavioral Sciences. 115: 138-146.

Iuliana, E., \& Criveanu, M., (2016). Financial and Non Financial Indicators For Organizational Performance Measurement. Faculty of Economics and Administration, Romania. 1-12.

Jamhour, M.S., \& Agha, S.H., (2010). The Impact of Core Competence on Organizational Performance. Middle East university. 1-134.

Jenatabadi, H.S., (2015). An Overview of Organizational Performance Index: Definitions and Measurements. International Journal of Business and Management. 8(19): 107-117.

Kerlinger, F.N. (2000). Azas-azas penelitian behavioral. Yogyakarta: Gajah Mada University Press.

Khan, R.A. (2012). Knowledge Management: A Framework for Competitive Advantage. Global Journal for Information Technology and Computer Science, vol. 1 (1).1 
The Effect of Organizational Performance, Competitive Advantage on the Financial Sector of Chemical

Manufacturing Industry in Banten Province

Nuryanto, Djamil MZ, Sutawidjaya, \& Saluy

Ko, W.H., (2015). Constructing a professional competence scale for foodservice research\& development employees from an industry viewpoint. International Journal of Hospitality Management. 49: 66-72.

Kusuma, F.S.D., \& Devie, (2013). Analisa Pengaruh Knowledge Management terhadap Keunggulan Bersaing dan Kinerja Perusahaan. Business Accounting Review. 1(2): 161-171.

Lee, V.H., Foo, A.T.L., Leong, L.Y., \& Ooi, K.B., (2016). Can Competitive Advantage be Achieved Through Knowledge Managemen A Case study on SMEs. 1-44.

Lestari, R \& Hertati, L.(2020). Bagaimana Pengaruh Strategi Bisnis, Kekuatan Produk Terhadap Kualitas Sistem Informasi Akuntansi Manajemen: Studi Kasus Pada Usaha Kecil Dan Menengah Di Indonesia. KAJIAN AKUNTANSI. 21(1)1-12.

Leonard-Barton, D. (1992). Core capabilities and core rigidities: A paradox in managing new product development. Strategic Management Journal, 13: 111-125.

Li, D.Y., Liu, J., (2012). Dynamic capabilities, environmental dynamism, and competitive advantage: Evidence from China. JBR Journal of Business Research. 1-7.

Li, S., Nathan, B.R., Nathan, T.S.R., \& Rao, S.S., (2006). The impact of supplychain management practices on competitiveadvantage and organizational performance. The International Journal of Management and Science. 34: 107-124.

Ling, T.N., Yih, G.C., Eze, U.C., Gan, G.G.G., \& Ling, L.P., (2008). Knowledge Management Drivers for Organizational Competitive Advantage. Proceeding of Applied international Business Conference. 501-510.

Lopez. S.P., \& Alegre, J., (2011). Information technology competency, knowledge processes and firm performance. Emerald Insight. 112(4): 644-662.

Lorenzo, J.R.F., Rubio, M.T.M., \& Garces, S.S. (2018). The competitive advantage in business, capabilities and strategy. What general performance factors are found in the Spanish wine industry?. Science Direct. 1-15.

Lysaght, R.M., Altschuld, J.W., Grant, H.K., \& Henderson, J.L., (2001). Variables Affecting the Competency Maintenance Behaviors of Occupational Therapists. AOTA. 55: 1-8.

MacLeod, A.K., \& Conway, C., (2007). Well-being and positive future thinking for the self versus others. Psychology Press. 21(5): 1114-1124.

Mahdavi, M.A.P., \& Pirzad, A., (2017). Study on Effect of Intellectual Capital on Knowledge Sharing. International Business Management. 11(3): 814-820.

Mahdi, O.R., Nassar, I.A., \& Almsafir, M.K., (2018). Knowledge management processes and sustainable competitive advantage: An empirical examination in private universities. Journal of Business Research. 2(13): 1-15.

Mansfield, R.S., Busse, T.V., \& Kreplka, E.J., (1978). The Effectiveness of Creativity Training. Review of Educational Journal.

McCelland, D.C. (1973). Testing for Competence Rather than for Intelligence. American Psychologist. 1-14.

McFadyen, M.A., \& Canella Jr, A.A., (2004). Social Capital and Knowledge Creation: Diminishing Returns of the Number and Strength of Exchange. Academy of Management. 47(5): 735-746.

Meiranto, W., Puspitasari, E., Sari, I.M., (2012). Pengelolaan Knowledge Management Capability Dalam Memediasi Dukungan Information technologies Relatedness Terhadap Kinerja Perusahaan: Pendekatan Reflective Second Order Factor. Jurnal Akuntansi AKRUAL. 3(2): 114-129. 
The Effect of Organizational Performance, Competitive Advantage on the Financial Sector of Chemical

Manufacturing Industry in Banten Province

Nuryanto, Djamil MZ, Sutawidjaya, \& Saluy

Morin, E.M., \& Audebrand, L.K., (2014). Organizational Performance and Meaning of Work: Correcting for Restricted Range. Organizational Performance and Meaning of Work. 1-19.

Munir, N.S., (2011). Penerapana Manajemen Pengetahuan di Perusahaan Indonesia. PPM of School Management. 1-13.

Muthuveloo, R., Shanmugam, N., Teoh, A.P., (2017). The impact of tacit knowledge management on organizational performance: Evidence from Malaysia. Asia Pacific Management Review. 1-10.

Nazarpour, M., Shirin, Z.B., (2017). Relation among Processes of Human Resources and Obtaining the Organizational Axial Capability with Intermediation Role of Knowledge Management Based on Modeling Structural Equations (Case Study: Khuzestan General Directorate of Ports and Maritime - Special Economic Zone of the Imam Khomeini Port). International Review of Management and Marketing. 7(3): 77-85.

Nimsith, S.I., Rifas, A.H., \& Cader, M.J.A., (2016). Impact of Core Competency on Competitive Advantage of Banking Firms in Sri Lanka. International Journal of Science Research and Innovative Technology. 3(7): 64-72.

Nowacki, R., \& Bachnik, K., (2015). Innovations within knowledge management. Journal of Business Research. 1-5.

Othman, R., Arshad, R., Aris, N.A., \& Arif, S.M.H., (2015). Organizational Resources and Sustained Competitive Advantage of Cooperative Organizations in Malaysia. Procedia Social and Behavior sciences. 170: 120-127.

Otoo, F.N.K., \& Mishra, M., (2018). Impact of Human Resource Management (HRM) Practices on Hotel Industry's Performance: The Mediating role of Employee Competencies. Indian Journal of Commerce \& Management Studies. 9(2): 17-29.

Penrose, E.T., (1959). The Theory of the Growth of the Firm. Oxford University Press: Oxford

Porter, M.E., (1985). Competitive Advantage: Creating and Sustaining Superior Performance: with a new introduction. The Free Press. New York, USA.

Sanchez, R. \& Heene, A. (1997). Reinventing strategic management: New theory and practice for competence-based competition, European Management Journal, 15(3), 303-317.

Syarudin, A \& Hertati, L. (2020). Penerapan Human Capital, Kualitas Pelayanan Pada Sistem Informasi Manajemen. 5 (1 ) 31-45

Safkaur, O, \& Herati, L. (2020). Perubahan Striktur Modal Menyebabkan Perubahan Struktur Modal. Jurnal Ekonomi Dan Perbankan 9(2) 94-105

Srivastava, S.C., (2005). Managing Core Competence of the Organization. VIKALPA. 30(4): 4963.

Stefanikova, L., \& Masarova, G., (2014). The need of complex competitive intelligence. Procedia Social and Behavior Sciences. 110: 669-677.

Stoner, C.R., 1987. Distinctive Competence and Competitive Advantage. Journal of Small Business Management. 25(2): 33-39.

Sulistyandari \& Handayani, (2011). Membangun Keunggulan Bersaing Berkelanjutan: Sebuah Kajian Literatur Pada Konteks Usaha Kecil dan Menengah. Jurnal Ekonomi Bisnis dan Akuntansi. 1 (1): 1-15.

Tsou, H.T., Chen, J.S., \& Liao, W.H., (2014). Market and technology orientations for service delivery innovation: the link of innovative competence. Journal of Business \& Industrial Marketing. 29(6): 499-513. 
The Effect of Organizational Performance, Competitive Advantage on the Financial Sector of Chemical Manufacturing Industry in Banten Province

Nuryanto, Djamil MZ, Sutawidjaya, \& Saluy

Turulja, R., \& Bajgoric, N., (2018). Knowing Means Existing: Organizational Learning Dimensions and Knowledge Management Capability. De Gruyter. 9(1): 1-19.

Zaied, A.N.H., Hussein, G.S., \& Hassan, M.M., (2012). The Role of Knowledge Management in Enhancing Organizational Performance. International Journal of Information Engineering and Electronic Business. 1-10. 